\title{
Nonculturable forms of bacteria in lyophilized probiotic preparations
}

\section{${ }^{1}$ Larisa Blinkova, ${ }^{2,3}$ Danik Martirosyan, ${ }^{1}$ Yury Pakhomov, ${ }^{1}$ Olga Dmitrieva, ${ }^{2}$ Rachel Vaughan, and ${ }^{1}$ Michael Altshuler}

${ }^{1}$ FGBU "Mechnikov Research Institute of Vaccines and Sera", Russian Academy of Medical Sciences, Moscow, 105064 Russia; ${ }^{2}$ Functional Food Center Inc., Richardson, TX 75390, USA; ${ }^{3}$ Department of Internal Medicine, UT Southwestern Medical Center, Dallas, TX 75390, USA

Submission date: August 3, 2013; Acceptance date: February 2, 2014; Publication date: February 9, 2014

Corresponding author: Larisa Blinkova, PhD, FGBU "Mechnikov Research Institute of Vaccines and Sera", Russian Academy of Medical Sciences, Moscow, 105064 Russia

\section{ABSTRACT}

Background: Nonculturable cells are formed under stress. These viable but nonculturable (VBNC) cells retain the ability to revert to active growth and division when conditions become favorable, or after treatment with resuscitating factors. Information about the possible presence of VBNC in bacterial lyophilized probiotic preparations, foodstuffs, live vaccines, etc., indicates that human as well as animal intestines are a significant area for research.

Methods: Samples were stored for different periods of time (up to 30 years) according to the manufacturers' manuals. Total counts were conducted using the Goryaev-Thoma counting chamber and actual viability was assessed by luminescence microscopy after staining with Live/Dead ${ }^{\circledR}\left(\right.$ Baclight $\left.^{\mathrm{TM}}\right)$. CFU/ml counts were made using solid or semisolid media. Viable cells that lacked the ability to form colonies were considered VBNC.

Results: We studied 11 batches of commercial probiotics (Russia) from different sources, containing lyophilized E. coli, lactobacilli, or bifidobacteria, in ampoules or vials. In E. coli preparations, depending on storage periods, the amounts of VBNC varied from $4.1 \%$ (3 years) to $99.7 \%$ (30 years) and showed different total viability $(52.2-91.3 \%)$, as well as the percentage of VBNC cells. A different sample that had been expired for 11 years was $79.5 \% \mathrm{NC}$. It is also noteworthy that the 5-dose vials, 4 years past expiration, from yet another source, showed a higher amount of VBNC cells $(85.5 \%)$. Two different batches that had been expired for three years contained 4.1 and $21.3 \%$ VBNC cells. 4 of the 5-dose vials of lyophilized lactobacilli were not expired and contained $58.8-80.4 \%$ VBNC cells. Total viability varied from 92.9 to $100 \%$, and there was an unmistakable positive correlation between total viability and culturability. The last batch, which had expired 6 years earlier, has $23.7 \%$ viable cells and about $98 \%$ VBNC. Nonexpired bifidobacterial samples contained 70.7 and $95.5 \%$ of viable cells and were 50 and $100 \%$ culturable.

Conclusion: We demonstrated the presence of VBNC cells in lyophilized probiotic preparations 
that contained live bacteria. Probiotics stored past their expiration date may retain a high potential medical effect because they contained high numbers of viable cells. VBNC cells in studied preparations may have the potential to return to an actively growing state.

Keywords: nonculturable forms of bacteria, probiotics

\section{INTRODUCTION:}

In adverse conditions of natural or artificial habitats (exhaustion of nutrient supplies and energy, non-optimal levels of temperature influence, oxygenation, influence of chemicals, toxins of the organic nature, sharp changes in $\mathrm{pH}$, exposure to white light, osmotic stress, etc.), non sporeforming microorganisms are exposed to stress that results in the formation of nonculturable forms of bacteria $[1-3 ; 5-6,8-12,16-17,19-20]$. Thus, cells that have left the proliferative cycle retain the potential to return to the active growth and reproduction phase [14]. The term "viable, but nonculturable" was assigned to conditions where the adverse conditions were reversible (viable but nonculturable - VBNC) [8, 9]. VBNC cells have entered a "state of dormancy triggered by harsh environmental conditions" $[16,21]$. Identification of the microorganisms in nonculturable states: in the environment, in humans, in animals, and in foodstuff, etc., is an important area of microbiological research. Apart from simply being viable and culturable or dead, cells can also be dormant (a state in which they are inactive but ultimately culturable) or active but nonculturable (as is the case with VBNC cells) [15].

Dormant conditions have different degrees of depths. In the presence of some stressful circumstances, the metabolism is slowed [1]; however, it can be measured and tested for [17]. At other conditions, the metabolism completely stops. For example, in a stationary phase, or in conditions of proliferative rest, cells keep metabolic activity $[1,2,3,10]$. This metabolic activity exists in the form of respiration or fermentation [16-17, 22-23]. Furthermore, cells may incorporate radioactive substances and have active protein synthesis [17]. While in other types of dormancy, there is a gradual slowing of metabolism [3, 4, 6, 9, 12]. Ametabolism (anabiosis, cryptobiosis, abiosis) $[1,13]$ is a condition in which a cell's metabolic processes have completely stop. However, ametabolism can be reversed under favorable conditions. Characteristics of a VBNC state include maintaining apparent cell integrity, having low metabolic activity, having reduced nutrient transport [15-18], exhibiting dwarfing, possessing apparent capacity to regain culturability in vivo [15-17], and higher autolytic capability than exponentially growing cells [17],

Depending on the factors inducing the transition to a dormant condition, the dormancy can either be classified as endogenous or exogenous [1, 13]. Endogenous dormancy is part of the natural cycle of development and is caused by a cell's internal mechanisms in reaction to stressful influences from its habitat. Dormant cells of this kind include bacterial and fungal spores, etc. $[12,14]$.

Exogenous rest is connected to the influence of external factors, such as the conservation of osmotically active agents (osmobiosis) such as salts, sucrose, etc., freezing (cryobiosis), and dehydrating (anhydrobiosis) in solutions. In our opinion, it is necessary to consider the lyophilization process of combining cryobiosis and anhydrobiosis, as well as the influence of low and high temperatures in conjunction with this type of dormancy [2]. 
Dormant nonculturable cells possess an increased resistance to damaging factors. For example, endospores are often able to withstand environmental factors such as heat and extreme $\mathrm{pH}$, exhibiting a "global resistance for prolonged periods of time" to such adverse conditions[16, 24-25]. However, upon the reversion from dormant forms to metabolic activity, the cells that are most adapted (a serotype, a clone, etc.) to changed environmental conditions can benefit from this advantage and dominate. Preservation of both viability and the possibility of returning to the active division can be estimated after millions of years [3]. However, there is an assumption that the formation of VBNC and the loss of the ability to form colonies is a stage of cell population decline [7]. It should be noted that cells incapable of forming colonies on standard nutrient media often have microscope-confirmed structural integrity. Furthermore, return from an endospore state to an active metabolic state in spore-forming bacteria and fungi can require multiple factors, sometimes interacting in a specific order. Some VBNC bacterial cultures have exhibited similar requirements $[16,18]$. It is therefore possible that some VBNC cultures require a more complex media to be resuscitated [16-18]. Some studies have shown that the retained metabolic activity of VBNC cells includes the ability of pathogenic cells to remain virulent in a VBNC state [17, 2627]. As it is known, microorganism colonies can be formed by more than one cell type, the biological activity of preparations connected with live bacteria (probiotics, vaccines, dietary supplements, etc.) is underestimated when only the CFU/ml is measured. Therefore, a question of studying the viability potential of lyophilized cells in long stored preparations not through $\mathrm{CFU} / \mathrm{ml}$, but directly through the calculation of living cells, is actually the purpose of the research: to find VBNC among lyophilized cells of industrial probiotics.

A popular method of determining viability of a culture is plate counting, which requires proliferation of a culture on a nutrient medium $[15,28]$. However, studies have shown a "striking difference" between plate count results and L/D count results (which use bioactive compounds to designate live and dead cells), as well as the possibility that a more complex medium may be required to return VBNC cells to a culturable state [17-18]. One study has suggested that plate count methods only accurately count cells which are viable and culturable on agar [15], which can cause issue due to the fact that less than $1 \%$ of microorganisms in natural water and soil samples can be cultured in such a way $[17,29]$. Although traditional laboratory culture conditions and methods often cannot meet the requirements of VBNC organisms to resume growth, being once again exposed to a favorable environment has shown the potential for VBNC cells to maintain significant activity and even resume proliferation [16-18]. Therefore, examining the true count of viable cells (both active and VBNC) could lead to much more accurate information about the functionality of certain foodstuffs.

\section{METHODS:}

The objects of research in this study were preparations of probiotics manufactured in vials and ampoules (preparations codes: Colibacterin - CB, Bificol - BFC, Bifidumbacterin - BB) produced by "Mechnikov BioMed" (the Moscow Region), "IMBIO" (Nizhny Novgorod), and "Mikrogen" (Stavropol) that were either non-expired or expired for different periods of time. These preparations were stored in a refrigerator according to the manufacturer's instructions. Characteristics of probiotics can be seen in table 1 . 
The total number of bacterial cells was counted in a Goryaev-Thoma counting chamber under a microscope ("Mikmed-5" of LOMO) with the magnification set on $320(8 \times 40)$. For the visual viability assessment, cells were stained with a commercial kit of bioluminescent dye Live/Dead ${ }^{\circledR}\left(\right.$ Baclight $\left.^{\mathrm{TM}}\right)$ under a luminescent microscope (Zeiss, Germany). Viable microorganisms with intact membranes had green luminescence, while dead microorganisms with damaged cytoplasmatic membranes were luminesced red.

Table 1 Characteristics of probiotic preparations used in this study.

\begin{tabular}{|c|c|c|c|c|c|c|}
\hline № & Trademark & Contents & $\begin{array}{l}\text { Manufac- } \\
\text { turer }\end{array}$ & $\begin{array}{l}\text { Place of } \\
\text { origin }\end{array}$ & $\begin{array}{l}\text { Batch codes, } \\
\text { expiration } \\
\text { date (year) }\end{array}$ & $\begin{array}{l}\text { Type of vessel, } \\
\text { number of doses }\end{array}$ \\
\hline 1 & Colibacterin & $\begin{array}{c}\text { Escherichia coli } \\
\text { M-17 }\end{array}$ & NIIVS & $\begin{array}{l}\text { Perm, } \\
\text { Russia }\end{array}$ & $\begin{array}{c}\text { CB 72-5 } \\
(1982)\end{array}$ & $\begin{array}{c}\text { Ampoules, } 3 \\
\text { doses }\end{array}$ \\
\hline 2 & Colibacterin & $\begin{array}{c}\text { Escherichia coli } \\
\text { M-17 }\end{array}$ & IMBIO & $\begin{array}{c}\text { Nizhny } \\
\text { Novgorod, } \\
\text { Russia }\end{array}$ & $\begin{array}{l}\text { CB 70-3 } \\
(2001)\end{array}$ & $\begin{array}{l}\text { Ampoules, } 3 \\
\text { doses }\end{array}$ \\
\hline 3 & Colibacterin & $\begin{array}{l}\text { Escherichia coli } \\
\text { M-17 }\end{array}$ & $\begin{array}{l}\text { Mechnikov } \\
\text { Biomed }\end{array}$ & $\begin{array}{l}\text { Moscow } \\
\text { region, } \\
\text { Russia } \\
\end{array}$ & $\begin{array}{l}\text { CB 4-3 } \\
(2008)\end{array}$ & Vials, 5 doses \\
\hline 4 & Colibacterin & $\begin{array}{l}\text { Escherichia coli } \\
\text { M-17 }\end{array}$ & $\begin{array}{l}\text { Mechnikov } \\
\text { Biomed }\end{array}$ & $\begin{array}{l}\text { Moscow } \\
\text { region, } \\
\text { Russia } \\
\end{array}$ & $\begin{array}{l}\text { CB 24-3 } \\
(2009)\end{array}$ & Vials, 5 doses \\
\hline 5 & Colibacterin & $\begin{array}{c}\text { Escherichia coli } \\
\text { M-17 }\end{array}$ & $\begin{array}{l}\text { Mechnikov } \\
\text { Biomed }\end{array}$ & $\begin{array}{l}\text { Moscow } \\
\text { region, } \\
\text { Russia }\end{array}$ & $\begin{array}{l}\text { CB 27-3 } \\
(2009)\end{array}$ & Vials, 5 doses \\
\hline 6 & Bificol & $\begin{array}{l}\text { Bifidobacterium } \\
\text { bifidum, Esche- } \\
\text { richia coli } \mathrm{M}-17\end{array}$ & $\begin{array}{l}\text { Mechnikov } \\
\text { Biomed }\end{array}$ & $\begin{array}{l}\text { Moscow } \\
\text { region, } \\
\text { Russia } \\
\end{array}$ & $\begin{array}{l}\text { BFC 20-1 } \\
2007\end{array}$ & Vials, 5 doses \\
\hline 7 & Bifidumbacterin & $\begin{array}{c}\text { Bifidobacterium } \\
\text { bifidum №1, } \\
791\end{array}$ & $\begin{array}{c}\text { FGUP } \\
\text { "NPO } \\
\text { Mikrogen" }\end{array}$ & $\begin{array}{c}\text { Stavropol, } \\
\text { Russia }\end{array}$ & BB 44 (2012) & Vials, 5 doses \\
\hline 8 & Bifidumbacterin & $\begin{array}{c}\text { Bifidobacterium } \\
\text { bifidum №1, } \\
791\end{array}$ & $\begin{array}{c}\text { FGUP } \\
\text { "NPO } \\
\text { Mikrogen" }\end{array}$ & $\begin{array}{l}\text { Stavropol, } \\
\text { Russia }\end{array}$ & BB 56 (2013) & Vials, 5 doses \\
\hline 9 & Lactobacterin & $\begin{array}{c}\text { Lactobacillus } \\
\text { plantarum or } L . \\
\text { fermentum }\end{array}$ & $\begin{array}{l}\text { Mechnikov } \\
\text { Biomed }\end{array}$ & $\begin{array}{l}\text { Perm, } \\
\text { Russia }\end{array}$ & $\begin{array}{l}\text { LB-55 } \\
(1994)\end{array}$ & $\begin{array}{l}\text { Ampoules, } 5 \\
\text { doses }\end{array}$ \\
\hline 10 & Lactobacterin & $\begin{array}{l}\text { Lactobacillus } \\
\text { plantarum } 8 \mathrm{R}- \\
\text { A3 or } 38 \text { or } L \text {. } \\
\text { fermentum } 90 \mathrm{~T}- \\
\text { S4 or } 39\end{array}$ & $\begin{array}{c}\text { FGUP } \\
\text { "NPO } \\
\text { Mikrogen" }\end{array}$ & $\begin{array}{l}\text { Perm, } \\
\text { Russia }\end{array}$ & $\begin{array}{l}\text { LB-80 } \\
(2010)\end{array}$ & Vials, 5 doses \\
\hline 11 & Lactobacterin & $\begin{array}{c}\text { Lactobacillus } \\
\text { plantarum } 8 \mathrm{R}- \\
\text { A3 or } 38 \text { or } L \text {. } \\
\text { fermentum } 90 \mathrm{~T}- \\
\text { S4 or } 39\end{array}$ & $\begin{array}{c}\text { FGUP } \\
\text { "NPO } \\
\text { Mikrogen" }\end{array}$ & $\begin{array}{l}\text { Perm, } \\
\text { Russia }\end{array}$ & LB 93 (2013) & Vials, 5 doses \\
\hline
\end{tabular}

Determination of $\mathrm{CFU} / \mathrm{ml}$ value for the cells of probiotic preparations was carried out by the standard plating of diluted suspensions of probiotics on a solid nutrient agar and Endo medium (E. coli) and on a semi-solid "Bifidum-medium" (for cultivation and allocation of Bifidumbacteria, produced by FGUN "State Scientific Center of Applied Microbiology" Obolensk). Nonculturable but viable forms of bacteria were revealed through the comparison of the total 
number of cells, the number of viable cells, and the number of bacteria that did not form a colony, per $1 \mathrm{ml}$. Experimental data was statistically analyzed. Mean values and their standard deviations (I95) were calculated (p 0,05).

\section{RESULTS:}

\section{Colibacterin}

The initial stage of our research was to assess the levels of viability of lyophilized bacteria in commercial probiotic preparations. The data obtained in these experiments is presented in table 2.

Table 2. Studying of Colibacterin samples in various periods of storage

\begin{tabular}{|c|c|c|c|c|c|}
\hline \multicolumn{2}{|c|}{$\begin{array}{c}\text { Characteristics of } \\
\text { Colibacterin }\end{array}$} & \multicolumn{4}{|c|}{ Biological parameters } \\
\hline \multirow[b]{2}{*}{$\begin{array}{c}\text { Batch codes, } \\
\text { expiration } \\
\text { date (year) }\end{array}$} & \multirow[b]{2}{*}{$\begin{array}{c}\text { Type } \\
\text { of vessel, } \\
\text { number of } \\
\text { doses }\end{array}$} & \multirow[b]{2}{*}{$\begin{array}{c}\text { Total number of cells in } \\
\text { Goryaev-Thoma camera } \\
\text { (cells/ml) }\left(\mathrm{I}_{95}\right) \\
\text { p value }\end{array}$} & $\begin{array}{c}\text { Live cells with "Live/Dead" } \\
(\%)\end{array}$ & \multirow[b]{2}{*}{$\begin{array}{c}\mathrm{CFU} / \mathrm{ml} \\
\left(\mathrm{I}_{95}\right) \\
\mathbf{p} \text { value }\end{array}$} & \multirow[b]{2}{*}{$\begin{array}{c}\mathrm{VBNC} \\
(\%)\end{array}$} \\
\hline & & & $\begin{array}{l}\text { Total number of live cells/ml } \\
\text { with "Live/Dead" }\left(I_{95}\right) \\
\text { p value }\end{array}$ & & \\
\hline 1 & 2 & 3 & 4 & 5 & 6 \\
\hline $\begin{array}{l}\text { CB 72-5 } \\
1982\end{array}$ & $\begin{array}{l}\text { Ampoules, } \\
3 \text { doses }\end{array}$ & $\begin{array}{c}2,11 \pm 0,23 \times 10^{10} \\
(1,56 \div 2,67) \times 10^{10} \\
3 \text { and } 4<0,05 \\
3 \text { and } 5<0,05\end{array}$ & $\begin{array}{c}52,2 \\
1,1 \pm 0,12 \times 10^{10} \\
(0,81 \div 1,39) \times 10^{10} \\
4 \text { and } 3<0,05 \\
4 \text { and } 5<0,05\end{array}$ & $\begin{array}{c}2,89 \pm 0,32 \times 10^{7} \\
(2,11 \div 3,65) \times 10^{7} \\
5 \text { and } 3<0,05 \\
5 \text { and } 4<0,05\end{array}$ & 99,73 \\
\hline $\begin{array}{l}\text { CB 70-3 } \\
2001\end{array}$ & $\begin{array}{l}\text { Ampoules, } \\
3 \text { doses }\end{array}$ & $\begin{array}{c}3,11 \pm 0,34 \times 10^{10} \\
(2,29 \div 3,93) \times 10^{10} \\
3 \text { and } 4>0,05 \\
3 \text { and } 5<0,05\end{array}$ & $\begin{array}{c}86,7 \\
2,7 \pm 0,3 \times 10^{10} \\
(1,98 \div 3,42) \times 10^{10} \\
4 \text { and } 3>0,05 \\
4 \text { and } 5<0,05\end{array}$ & $\begin{array}{c}5,55 \pm 0,61 \times 10^{9} \\
(4,09 \div 7,01) \times 10^{9} \\
5 \text { and } 3<0,05 \\
5 \text { and } 4<0,05\end{array}$ & 79,5 \\
\hline $\begin{array}{l}\text { CB } 4-3 \\
2008\end{array}$ & $\begin{array}{l}\text { Vials, } \\
5 \text { doses }\end{array}$ & $\begin{array}{c}1,21 \pm 0,13 \times 10^{10} \\
(0,89 \div 1,52) \times 10^{10} \\
3 \text { and } 4>0,05 \\
3 \text { and } 5<0,05\end{array}$ & $\begin{array}{c}90,3 \\
1,091 \pm 0,12 \times 10^{10} \\
(0,80 \div 1,38) \times 10^{10} \\
4 \text { and } 3>0,05 \\
4 \text { and } 5<0,05\end{array}$ & $\begin{array}{c}1,58 \pm 0,17 \times 10^{9} \\
(1,17 \div 1,99) \times 10^{9} \\
5 \text { and } 3<0,05 \\
7 \text { and } 4<0,05\end{array}$ & 85,5 \\
\hline $\begin{array}{l}\text { CB 24-3 } \\
2009\end{array}$ & $\begin{array}{l}\text { Vials, } \\
5 \text { doses }\end{array}$ & $\begin{array}{c}1,44 \pm 0,15 \times 10^{10} \\
(1,08 \div 1,8) \times 10^{10} \\
3 \text { and } 4>0,05 \\
3 \text { and } 5>0,05\end{array}$ & $\begin{array}{c}88,2 \\
1,27 \pm 0,14 \times 10^{10} \\
(0,90 \div 1,58) \times 10^{10} \\
4 \text { and } 3>0,05 \\
4 \text { and } 5>0,05\end{array}$ & $\begin{array}{c}1 \pm 0,11 \times 10^{10} \\
(0,74 \div 1,26) \times 10^{10} \\
5 \text { and } 3>0,05 \\
5 \text { and } 4>0,05\end{array}$ & 21,3 \\
\hline $\begin{array}{l}\text { CB 27-3 } \\
2009\end{array}$ & $\begin{array}{l}\text { Vials, } \\
5 \text { doses }\end{array}$ & $\begin{array}{c}1,32 \pm 0,14 \times 10^{10} \\
(0,98 \div 1,66) \times 10^{10} \\
3 \text { and } 4>0,05 \\
3 \text { and } 5>0,05\end{array}$ & $\begin{array}{c}91,3 \\
1,2 \pm 0,13 \times 10^{10} \\
(0,89 \div 1,51) \times 10^{10} \\
4 \text { and } 3>0,05 \\
4 \text { and } 5>0,05\end{array}$ & $\begin{array}{c}1,16 \pm 0,13 \times 10^{10} \\
(0,85 \div 1,47) \times 10^{10} \\
5 \text { and } 3>0,05 \\
5 \text { and } 4>0,05\end{array}$ & 4,13 \\
\hline
\end{tabular}


As it appears in table 2, lyophilized Colibacterin (5 batches), from different manufacturers that had been expired for different periods of time (from 1982 to 2009), were studied. In the Colibacterin preparation, the sample was manufactured in 3-dose ampoules (CB 72-5, production of the Perm NIIVS) with an excess storage period of almost 30 years, $99.73 \%$ of the living cells did not form colonies. As it was established under a microscope with a Live/Dead kit, the sample contained $52,2 \%(1,1 \pm 0,12 \times 1010$ cells $/ \mathrm{ml})$ of viable cells. The total number of cells was $2,11 \pm 0,23 \times 1010$ cells $/ \mathrm{ml}$. The culturability assessment of this preparation resulted with $2,89 \pm 0,32 \times 107 \mathrm{CFU} / \mathrm{ml}$.

The Colibacterin utilized was manufactured in $3 \mathrm{ml}$ ampoules by Nizhny Novgorod "IMBIO," 11 years past expiration. $79,5 \%$ of its cells were incapable of colony formation. The $\mathrm{CFU} / \mathrm{ml}$ of this sample equaled $5,55 \pm 0,61 \times 10^{9} / \mathrm{ml}$, the difference between CFU $/ \mathrm{ml}$ and total number of cells is $3,11 \pm 0,34 \times 10^{10} / \mathrm{ml}$ in the Goryaev-Thoma camera.

The fact that a higher number of viable E. coli bacteria was not able to form colonies $(85.5 \%)$ in a preparation produced by Mechnikov Biomed that was stored for 4 years past expiration is interesting $(\mathrm{p}<0,05)$, i.e. values were statistically reliable. It should be noted that it was manufactured in 5 dose vials. The percent of the living cells revealed using a Live/Dead kit was 90.3\%. This value shows on the statistical equality to total number of cells in Goryaev-Thoma camera and value of live cells with "Live/Dead", i.e. values were statistically doubtful ( $p>0,05)$.

Colibacterin from two batches (code CB 24-3 and CB 27-3) produced by Mechnikov Biomed, 3 years past their expiration, had viability rates of $88.2 \%$ and $91.3 \%$, respectively. The indicator of the inability to form colonies was $21.3 \%$ and $4.13 \%$ for each of the two batches. All these parameters were statistically doubtful $(p>0,05)$, which shows a high level of cell viability and a small number of VBNC.

\section{Bifidobacterin}

As it is presented in table 3, for the preparations containing bifidobacteria (from three producers) which were stored for 2 and 5 years past expiration or still non-expired, we observed (according to luminescent microscopy) a high level of the preservation of viability in a mix of cells (70.3\% for "Bificol", BFC-20-1).

The "Bifidumbacterin" preparations, produced in 5 dose vials by the Federal State Unitary Enterprise "NPO Mikrogen," Stavropol, without excess of periods of storage, reveal a level of cell viability from $70.7 \%$ to $95.45 \%$. In the bifidobacteria reculturing of some batches (code BB56 and BB-44), in the environment for their cultivation, there was a delay in the emergence of visual colony growth up to the 72nd hour (microscopic colonies were formed after 4 and 7 days and would later develop into normal colonies). In the first days of incubation in these preparations, no more than $0.01 \%$ could be revealed from the total number of the bifidobacteria that were able to form colonies.

For the "Bifidumbacterin" batch with an expiration date of 01/2008, we made an attempt to increase the number of colonies by the addition of $1 \%$ and $10 \%$ Aminopeptide in the final concentration. In the test tubes with additives, during the later days of incubation, a 2-fold increase in the numbers of culturable cells in comparison with the control (medium without Aminopeptide addition) was noted. These results allow us to assume that there was a transition of non culturable forms to a vegetative condition. 
Table 3. Studying of samples probiotic preparations, containing bifidobacteria with various periods of storage

\begin{tabular}{|c|c|c|c|c|c|c|c|}
\hline \multicolumn{3}{|c|}{ Characteristics of preparation } & \multicolumn{5}{|c|}{ Biological parameters } \\
\hline \multirow[b]{2}{*}{$\begin{array}{l}\text { Prepa- } \\
\text { rations }\end{array}$} & \multirow[b]{2}{*}{$\begin{array}{l}\text { Codes of } \\
\text { batches, } \\
\text { expiration } \\
\text { date } \\
\text { (year) }\end{array}$} & \multirow[b]{2}{*}{$\begin{array}{c}\text { Type of } \\
\text { vessel, } \\
\text { number of } \\
\text { doses }\end{array}$} & \multirow[b]{2}{*}{$\begin{array}{l}\text { Total number of } \\
\text { cells in } \\
\text { Goryaev-Thoma } \\
\text { camera } \\
\text { (cells } / \mathrm{ml} \text { ) }\left(\mathrm{I}_{95} \text { ) }\right. \\
\mathbf{p} \text { value }\end{array}$} & $\begin{array}{l}\text { live cells with } \\
\text { "Live/Dead" } \\
(\%)\end{array}$ & \multicolumn{3}{|c|}{$\begin{array}{c}\mathrm{CFU} / \mathrm{ml} \\
\text { (incubation time) }\end{array}$} \\
\hline & & & & $\begin{array}{l}\text { total number of } \\
\text { live cells/ml } \\
\text { with“Live/Dead } \\
\text { " }\left(\mathrm{I}_{95}\right) \mathbf{p} \text { value }\end{array}$ & $24 \mathrm{~h}$. & $72 \mathrm{~h}$. & $\begin{array}{l}\text { maximum } \\
\left.\text { CFU/ml ( }{ }_{95}\right) \\
\text { p value }\end{array}$ \\
\hline 1 & 2 & 3 & 4 & 5 & 6 & 7 & 8 \\
\hline \multirow[t]{2}{*}{ Bificol } & \multirow{2}{*}{$\begin{array}{c}\text { BFC 20-1 } \\
2007\end{array}$} & \multirow{2}{*}{$\begin{array}{l}\text { Vials, } \\
5 \text { doses }\end{array}$} & \multirow{2}{*}{$\begin{array}{c}5,96 \pm 0,66 \times 10^{8} \\
(4,38 \div 7,54) \times 10^{8} \\
4 \text { and } 5>0,05 \\
4 \text { and } 8 \geq 0,05\end{array}$} & 70,3 & \multirow{2}{*}{$\begin{array}{l}\text { No } \\
\text { growth }\end{array}$} & \multirow[t]{2}{*}{ No growth } & $\begin{array}{c}1 \pm 0,11 \times 10^{9} \\
\text { B. bifidum } \\
(0,74 \div 1,26) \times 10^{9} \\
8 \text { and } 4 \geq 0,05 \\
8 \text { and } 5>0,05\end{array}$ \\
\hline & & & & $\begin{array}{c}4,19 \pm 0,46 \times 10^{8} \\
(3,09 \div 5,29) \times 10^{8} \\
5 \text { and } 4>0,05 \\
5 \text { and } 8>0,05\end{array}$ & & & $\begin{array}{c}1,25 \pm 0,14 \times 10^{7} \\
\text { E. coli }\end{array}$ \\
\hline \multirow[b]{2}{*}{$\begin{array}{c}\text { Bifdumbac- } \\
\text { terin }\end{array}$} & \multirow[b]{2}{*}{$\begin{array}{c}\text { BB } 44 \\
2012\end{array}$} & \multirow[b]{2}{*}{$\begin{array}{l}\text { Vials, } \\
5 \text { doses }\end{array}$} & \multirow{2}{*}{$\begin{array}{c}2,92 \pm 0,32 \times 10^{7} \\
(2,15 \div 3,69) \times 10^{7} \\
4 \text { and } 5>0,05 \\
4 \text { and } 8<0,05\end{array}$} & 70,7 & \multirow[b]{2}{*}{$\begin{array}{l}\text { No } \\
\text { growth }\end{array}$} & \multirow[b]{2}{*}{$3,6 \pm 0,4 \times 10^{4}$} & \multirow{2}{*}{$\begin{array}{c}1 \pm 0,11 \times 10^{7} \\
(0,74 \div 1,26) \times 10^{7} \\
8 \text { and } 4<0,05 \\
8 \text { and } 5>0,05\end{array}$} \\
\hline & & & & $\begin{array}{c}2,06 \pm 0,23 \times 10^{7} \\
(1,51 \div 2,61) \times 10^{7} \\
5 \text { and } 4>0,05 \\
5 \text { and } 8>0,05\end{array}$ & & & \\
\hline $\begin{array}{c}\text { Bifdumbac- } \\
\text { terin }\end{array}$ & $\begin{array}{c}\text { BB } 56 \\
2013\end{array}$ & $\begin{array}{l}\text { Vials, } \\
5 \text { doses }\end{array}$ & $\begin{array}{c}6,76 \pm 0,74 \times 10^{7} \\
(4,98 \div 8,54) \times 10^{7} \\
4 \text { and } 5>0,05 \\
4 \text { and } 8>0,05\end{array}$ & $\begin{array}{c}95,45 \\
6,45 \pm 0,71 \times 10^{7} \\
(4,75 \div 8,15) \times 10^{7} \\
5 \text { and } 4>0,05 \\
5 \text { and } 8>0,05\end{array}$ & $\begin{array}{c}6 \pm 0,66 \\
\times 10^{7}\end{array}$ & $2 \pm 0,22 \times 10^{8}$ & $\begin{array}{l}2 \pm 0,22 \times 10^{8} \\
(1,47 \div 2,53) \\
8 \text { and } 4>0,05 \\
8 \text { and } 5>0,05\end{array}$ \\
\hline
\end{tabular}

\section{Lactobacterin.}

The results relating to the viability of lyophilized lactobacillus are presented in table 4 . The quantity of cells not forming colonies (VBNC) varied from $54.4 \%$ to $99.9 \%$. The greatest percent of cells that passed to VBNC is noted for LB-55 (1994). 92\% of the living cells in Lactobacterin (exp. 2010) were not forming colonies. In another sample (exp. 2013) the quantity of VBNC was equal to or less than $54.4 \%(\mathrm{p}<0,05)$. Therefore, the percent of the living cells that had lost the ability to form colonies depended on the date that the probiotic preparation was produced.

Therefore, in each of the studied preparations we found a certain percent of viable, but nonculturable bacteria, which are potentially capable of proliferation in favorable conditions. 
Table 4. Studying of samples probiotic preparations, containing lactobacteria with various periods of storage

\begin{tabular}{|c|c|c|c|c|c|c|}
\hline \multicolumn{3}{|c|}{ Characteristics of preparation } & \multicolumn{4}{|c|}{ Biological parameters } \\
\hline \multirow{3}{*}{ Preparations } & \multirow{3}{*}{$\begin{array}{l}\text { Codes of } \\
\text { batches, } \\
\text { expiration } \\
\text { date } \\
\text { (year) }\end{array}$} & \multirow{3}{*}{$\begin{array}{c}\text { Type of } \\
\text { vessel, } \\
\text { number of } \\
\text { doses }\end{array}$} & \multirow{2}{*}{$\begin{array}{l}\text { Total number of } \\
\text { cells in } \\
\text { Goryaev- } \\
\text { Thoma camera } \\
\text { (cells/ml), I } \text { I }_{95}\end{array}$} & $\begin{array}{l}\text { live cells with } \\
\text { "Live/Dead" (\%) }\end{array}$ & \multirow{2}{*}{$\begin{array}{c}\mathrm{CFU} / \mathrm{ml} \\
\text { (Incubation } \\
\text { time }=72 \mathrm{~h}) \text {, } \\
\left(\mathrm{I}_{95}\right)\end{array}$} & \multirow{3}{*}{$\begin{array}{l}\mathrm{VBNC} \\
(\%)\end{array}$} \\
\hline & & & & $\begin{array}{l}\text { total number of live } \\
\text { cells/ml with } \\
\text { "Live/Dead", } \mathrm{I}_{95}\end{array}$ & & \\
\hline & & & p value & $\mathbf{p}$ value & p value & \\
\hline 1 & 2 & 3 & 4 & 5 & 6 & 7 \\
\hline \multirow{4}{*}{ Lactobacterin } & \multirow{4}{*}{$\begin{array}{c}\text { LB-55 } \\
1994\end{array}$} & \multirow{4}{*}{$\begin{array}{l}\text { Ampoules, } \\
5 \text { doses }\end{array}$} & \multirow{3}{*}{$\begin{array}{l}3,4 \pm 0,37 \times 10^{9} \\
(2,5 \div 4,3) \times 10^{9}\end{array}$} & 66,5 & \multirow{2}{*}{$\begin{array}{c}1,0 \pm 0,11 \times 10^{7} \\
(0,74 \div 1,26) \times 10^{7}\end{array}$} & \multirow{4}{*}{99,9} \\
\hline & & & & $\begin{array}{l}2,3 \pm 0,25 \times 10^{9} \\
(1,7 \div 2,9) \times 10^{9}\end{array}$ & & \\
\hline & & & & & \multirow{2}{*}{$\begin{array}{l}6 \text { and } 4<0,05 \\
6 \text { and } 5<0,05\end{array}$} & \\
\hline & & & $\begin{array}{l}4 \text { and } 5>0,05 \\
4 \text { and } 6<0,05\end{array}$ & $\begin{array}{l}5 \text { and } 4>0,05 \\
5 \text { and } 6<0,05\end{array}$ & & \\
\hline \multirow{4}{*}{ Lactobacterin } & \multirow{4}{*}{$\begin{array}{c}\text { LB-80 } \\
2010\end{array}$} & \multirow{4}{*}{$\begin{array}{l}\text { Vials, } \\
5 \text { doses }\end{array}$} & & 92,04 & \multirow{4}{*}{$\begin{array}{c}2,1 \pm 0,22 \times 10^{9} \\
(1,57 \div 2.63) \\
\times 10^{9} \\
6 \text { and } 4 \geq 0,05 \\
6 \text { and } 5>0,05\end{array}$} & \multirow{4}{*}{92,0} \\
\hline & & & $\begin{array}{c}3,3 \pm 0,3 \times 10^{9} \\
(2,6 \div 4,02) \times 10^{9}\end{array}$ & $3,06 \pm 0,23 \times 10^{9}$ & & \\
\hline & & & & & & \\
\hline & & & $\begin{array}{l}4 \text { and } 5>0,05 \\
4 \text { and } 6 \geq 0,05\end{array}$ & $\begin{array}{l}5 \text { and } 4>0,05 \\
5 \text { and } 6>0,05\end{array}$ & & \\
\hline \multirow{4}{*}{ Lactobacterin } & \multirow{4}{*}{$\begin{array}{l}\text { LB } 93 \\
2013\end{array}$} & \multirow{4}{*}{$\begin{array}{l}\text { Vials, } \\
5 \text { doses }\end{array}$} & & 99,9 & \multirow{3}{*}{$\begin{array}{c}1,35 \pm 0,15 \times 10^{9} \\
(0,99 \div 1,71) \times 10^{9}\end{array}$} & \multirow{4}{*}{54,4} \\
\hline & & & $2,9 \pm 0,3 \times 10^{9}$ & $2,9 \pm 0,3 \times 10^{9}$ & & \\
\hline & & & $(2,18 \div 3,62) \times 10^{\prime}$ & $(2,18 \div 3,62) \times 10^{9}$ & & \\
\hline & & & $\begin{array}{l}4 \text { and } 5>0,05 \\
4 \text { and } 6<0,05\end{array}$ & $\begin{array}{l}5 \text { and } 4>0,05 \\
5 \text { and } 6>0,05\end{array}$ & $\begin{array}{l}6 \text { and } 4<0,05 \\
6 \text { and } 5>0,05\end{array}$ & \\
\hline
\end{tabular}

\section{DISCUSSION:}

In our opinion, the obtained data indicates the presence of VBNC forms in lyophilized probiotic bacteria preparations. In such conditions of artificial anabiosis, these nonculturable forms can submit to the same laws of preservation and restoration that they do in nature. So, for the cells that have undergone lyophilization, Belgian scientists [4] studying a nonculturable condition of methane oxidizing bacteria have been led to a similar conclusion. Authors demonstrate that preservation (lyophilization, cryopreservation) induced VBNC state in significant part of cells.

It should be noted that suspensions of $E$. coli M17, which was incubated at room temperature in tubes with normal saline (an environment deprived of nutrients) and initially contained only singular CFU/ml for 72 hours, that were 30 years past expiration from Colibacterin, yielded an essential increase in culturability (by 3 orders of magnitude) that was clearly impossible to achieve by the division of the initial CFUs. A comparison of the results from plating the suspensions after the cultivations, which have shown a single quantity of CFU/ml after an initial resuspending of a probiotic, indicates that, in a nutritious agar, a statistically significant increase in concentration of bacteria ( 3 orders of magnitude) for a single cell in a hungry environment is impossible. Apparently, there was a restoration of damaged cells during the lyophilization process 
or a storage of cells (a stressful factor), where the cells lose their ability to quickly transition to a condition of growth and reproduction.

The obtained data on nonculturable forms is important for controlling the true viability of cells in commercial lyophilized preparations based on microbial cells. The expiration date of such preparations, in our opinion, can be increased because of their containment of viable, but not readily culturable, cells. Aminopeptide (1\% and 10\%) is one of the factors that can transform nonculturable bacteria into a vegetative culturable state of bifidobacteria. For example, once in the intestines of a person or animal, these unaccounted nonculturable forms of probiotic microorganisms can start developing, providing for probiotics a long and effective influence. The approved method for assessing viability is also an express method for identifying viable cells in comparison with a method for defining CFU/ml.

Although some studies have been done on the ability of pathogenic VBNC cells to resuscitate in a complex environment, little consideration has been given thus far to the similar potential of probiotic substances. While the ultimate culturability of VBNC cells may currently be unclear [15], a variety of studies have shown that bacteria such as E. coli can remain inactive in foods and then resuscitate in the complex environment of the human gut [16-18]. More research into the potential of probiotics and other VBNC-containing functional foods may well shed light on further functionality as a result of complex resuscitation.

Although there does appear to be a direct correlation between the amount of cells that cannot form colonies and the amount of time that has passed since the preparation of cells had been produced, a significant amount of these non-reproductive cells remained viable. Furthermore, their viability was such that these non-reproductive cultures had the potential to resume proliferation when reintroduced to favorable conditions. This ability to remain alive in a dormant state, and even resume reproduction under the correct circumstances, presents an interesting potential for revival of "expired" cultures. Since so few similar studies have been done thus far, it would be beneficial for more research to be done on which factors most influence a specific culture's going in to, and coming out of, a dormant state, and how easy it is to manipulate those factors.

Conclusion: We demonstrated the presence of VBNC cells in lyophilized probiotic preparations that contained live bacteria. Probiotics stored past their expiration date may retain a high potential medical effect because they contained high numbers of viable cells. VBNC cells in studied preparations may have the potential to return to an actively growing state.

Competing interests: The authors declare that they have no competing interests.

Authors' contributions: Dr. Blinkova offered idea of experiment, a technique of its carrying out, is the principal investigator for the study, interpreted results of experiment and writing this article. Dr. Martirosyan provided discussion of the results, and assisted in writing this article. Pakhomov provided experiments, participated in discussion and registration of results and in writing this article. Dmitrieva O. provided experiments, participated in analyze, discussion and registration of results. Rachel Vaughan assisted in writing and editing this article. Altshuler M. participated in discussion of results. 


\section{REFERENCES:}

1. Blinkova L, Pakhomov Yu, Stoyanova L. Properties of non culturable and dormant microorganisms. Immunology, Allergology, Infectology. (Moscow), 2010; 3: 67-76.

2. Blinkova L, Pakhomov Yu, Nikiforova $\mathrm{O}$ et al. Express assessment of cell viability in biological preparation. Pharmaceutical and medical biotechnology. Moscow: "Expobiochem-technology". 2012: 391-392.

3. Bukharin O, Gintsburg A, Romanova Yu, El-Registan G. Survivability mechanisms of bacteria. Moscow, "Meditsina", 2005.

4. Hoefman S, Van Hoorde K, Boon N et al. Survival or Revival: long-term preservation induces a reversible viable but nonculturable state in methane-oxidizing bacteria. 2012; Plos One 7(4); e34196, doi: 10, 1371: 2-16.

5. Mukamolova G, Yasnopolskaya N, Kell D, Kaprelyants A. On resuscitation from the dormant state of Micrococcus luteus. Antonie van Leeuwenhoek, 1998; 73(3): 237-243.

6. Mulyukin A. Dormant forms of non spore former bacteria. Properties, veriety, diagnostics. Autoref. diss. Dr. biol. sciences. Moscow, 2010.

7. Nyström T. Not-quite dead enough: on bacterial life, culturability, senescence, and death. Arch. Microbiol, 2001; 176: 159-164.

8. Oliver J. The viable but nonculturable state in the human pathogen, Vibrio vulnificus. FEMS Microbial. Lett., 1995; 133: 203-208.

9. Oliver J. Recent findings on the viable but nonculturable state in pathogenic bacteria. FEMS Microbial Rev., 2010; 34: 415-425.

10. Pakhomov Yu, Blinkova L, Stoyanova L. The role of nonculturable forms not spore former bacteria with population gomeostasis support. Immunology, Allergology, Infectology, 2010; 4: 57-66.

11. Pakhomov Yu, Blinkova L, Stoyanova L, Dmitrieva O. Nonculturable forms of Lactococcus lactis. Annales of Nutrition and Metabolism 62 (suppl. 2); 22.

12. Romanova Yu, Gintsburg A. Whether there is a similarity in creation mechanisms "not cultivated forms" at gram-negative bacteria and spores at bacilli? Mol. Genetics, Microbiology, Virusology (Moscow), 1993, 6: 34-37.

13. Senoh M, Ghosh-Banerjee, Ranamurthy Th, Hamabata T, Kurakawa T, Takeda M, Colwell R, Nair G, Takeda Y. Conversion of viable but nonculturable Vibrio cholerae to the culturable state by co-culture with eukaryotic cells. Microbiol. Immunol., 2010; 54: 502507.

14. 14.Sussman A, Halvorson H. Spores. Their dormancy and germination. New York: Harper \& Row; 1966: 203 p.

15. Lahtinen, Sampo J, Miguel Gueimonde, Arthur C. Ouwehand, Johanna P. Reinikainen, and Seppo J. Salminen. Probiotic Bacteria May Become Dormant During Storage. Applied and Environmental Microbiology, 2005; 71(3).

16. Nicolo, Marco Sebastiano and Salvatore Pietro Paolo Guglielmino.(2012). Viable but Nonculturable Bacteria in Food, Public Health - Methodology, Environmental and Systems Issues, Prof. Jay Maddock (Ed.), ISBN: 978-953-51-0641-8, InTech, DOI: 10.5772/38118. Available from: http://www.intechopen.com/books/public-health- 
methodology-environmental-and-systems-issues/viable-but-not-culturable-bacteria-infood

17. Fakruddin, Md, Khanjada Shahnewaj Bin Mannan, and Stewart Andrews. Viable But Nonculturable Bacteria: Food Safety and Public Health Perspective. ISRN Microbiology, vol. 2013, Article ID 703813, 6 pages, 2013. doi:10.1155/2013/703813

18. Castellani, Fancesco, Valentina Ghidini, Maria Garla Tafi, Marzia Boaretti, and Maria M. Leo. Fate of Pathogenic Bacteria in Microcosms Mimicking Human Body Sites. Microbial Ecology, Springer Science and Business Media New York, 2013.

19. E. Cunningham, C. O'Byrne, and J. D. Oliver, "Effect of weak acids on Listeria monocytogenessurvival: evidence for a viable but nonculturable state in response to low pH," Food Control, vol. 20, no. 12, pp. 1141-1144, 2009.

20. E. Aizenman, H. Engelberg-Kulka, and G. Glaser, "An Escherichia coli chromosomal "addiction module" regulated by 3', 5'-bispyrophosphate: a model for programmed bacterial cell death,"Proceedings of the National Academy of Sciences of the United States of America, vol. 93, no. 12, pp. 6059-6063, 1996.

21. Cook, K.L. \& Bolster, C.H. (2007). Survival of Campylobacter jejuni and Escherichia coli in Groundwater During Prolonged Starvation at Low Temperatures. Journal of Applied Microbiology, Vol.103, No.3, (September 2007), pp. 573-583, ISSN 1364-5072

22. Porter, J., Edwards, C. \& Pickup, R.W. (1995). Rapid Assessment of Physiological Sstatus in Escherichia coli Using Fluorescent Probes. Journal of Applied Bacteriology, Vol.79, No.4, (October 1995), pp. 399-408, ISSN 1364-5072

23. Oliver, J.D. (2000). Problems in Detecting Dormant (VBNC) Cells and the Role of DNA Elements in This Response, In: Tracking Genetically-engineered Microorganisms, J.K. Jansson, J.D. van Elsas, and M.J. Bailey (eds.), 1-15, Landes Biosciences, ISBN 978-158706-009-0, Georgetown, Texas, USA.

24. Matin, A. (1991). The Molecular Basis of Carbon-Starvation-Induced General Resistance in Escherichia coli. Molecular Microbiology, Vol.5, No.1, (January 1991), pp. 3-10, ISSN 0950-382X

25. Nyström, T., Olsson, R.M. \& Kjelleberg, S. (1992). Survival, Stress Resistance, and Alterations in Protein Expression in the Marine Vibrio sp. Strain S14 during Starvation for Different Individual Nutrients. Applied and Environmental Microbiology, Vol.58, No.1, (January 1992), pp. 55-65, ISSN 0099-2240

26. W. Baffone, B. Citterio, E. Vittoria et al., "Retention of virulence in viable but nonculturable halophilic Vibrio spp," International Journal of Food Microbiology, vol. 89, no. 1, pp. 31-39, 2003.

27. Y. N .Sardessai, "Viable but non-culturable bacteria: their impact on public health," Current Science, vol. 89, p. 1650, 2005.

28. Kell, D. B., A. S. Kaprelyants, D. H. Weichart, C. R. Harwood, and M. R. Barer. 1998. Viability and activity in readily culturable bacteria: a review and discussion of the practical issues. Antonie Leeuwenhoek 73:169-187.

29. I. Barcina and I. Arana, "The viable but nonculturable phenotype: a crossroads in the lifecycle of non-differentiating bacteria?" Reviews in Environmental Science and Biotechnology, vol. 8, no. 3, pp. 245-255, 2009. 